\title{
THE IMPACT OF ORGANIZATIONAL CLIMATE ON TEACHERS' JOB PERFORMANCE
}

\author{
Nurharani Selamat \\ Nur Zahira Samsu \\ Nur Shaminah Mustafa Kamalu \\ Faculty of Education, Universiti Teknologi MARA, Shah Alam, Malaysia
}

\begin{abstract}
:
Teachers' job performance is the way in which a teacher behaves in the process of teaching and it is known to be related to teachers' effectiveness. It is said that good performance of students depends upon effective teaching of their teachers. Thus, it is important to examine the factor that could enhance teachers' job performance in school. The main purpose of this study was to examine the influence of organizational climate on teachers' job performance. 37 secondary school teachers in the district of Klang participated in this study. They were selected based on simple random sampling. Data were collected using the survey method and were analyzed using descriptive statistic and inferential statistic. Based on the data collected, the findings showed that teachers in a secondary school were unable to carry out their tasks and the organizational climate in the school was unhealthy. The study also showed that organizational climate was found to be a significant factor that could affect teachers' job performance. In terms of organizational climate dimensions, one aspect of principal's leadership behavior and teachers' behavior: thrust and hindrance were found to be critical factors in enhancing teachers' job performance. The findings of this study have implications to the role of principal in exercising positive job behavior and do not over emphasize on paper work as it would benefit teachers' classroom instruction and students' academic achievement. Based on the findings, this study also provides recommendations for practices and future research.
\end{abstract}

Keywords: Organizational climate; job performance; teacher.

Corresponding author: Nurharani Selamat

E-mail: nurharani@gmail.com

Submitted for publication 13/01/2013

Accepted for publication 25/01/2013

Educational Research eJournal ISSN 2254-0385

(C) Faculty of Education. University of Alicante

DOI: 10.5838/erej.2013.21.06 


\section{Introduction}

Development of nation is primarily dependent on the education system available in the country. Education is no where without teacher's playing a pivotal role in ensuring achievement in a educational institution. Teacher's job performance play a crucial role in student's learning process. It is known to be related to teacher's effectiveness (Medly and Shannon, 1994). Teachers play a basic and dynamic role in the educational system. It is said that good performance of students depends upon effective teaching of their teachers. As professionals, teachers need to be appropriate role models and exhibit to their students a commitment to scholarly values and to life-long learning (Medly and Shannon, 1994). One factor that might influence teacher's job performance is organizational climate. The organizational climate dimensions were measured based on principal's leadership behavior and teacher's behavior. Principals can encourage effective performance of their teachers by identifying their needs and try to meet them (Adeyemi, 2010). This encouragement is very much dependent on various aspects of the principal's leadership behavior. Teacher's behavior too plays a role in the teacher's job performance. Both principals' behavior and teachers' behavior are part of organizational climate which influence the teacher's job performance.

Teachers are arguably the most important group of professionals for our nation's future. Without teacher, the education system will be crippled. The increased importance in teacher's job performance has made it extremely important to identify the factors that influence teacher's job performance. In recent years, effects of organizational climate on teacher's performance have become topic of concerns for researchers and education officers. Although numerous studies have been conducted on teacher's job performance, past research has been constrained by the shortage of studies on the influence of organizational climate on teacher's job performance. Number of reports has shown that teacher's job performance is deteriorating around the world in general, and also Malaysia in particular. This seems to be affecting the teaching and learning process as well other instructional activities at school. As a result, students are the most affected individuals. Hence, it is crucial to determine the factor that has influence in teacher's job performance.

Job performance referred to an act of accomplishing or executing a given task (Lindsay, 1995; Griffin, 2012). Teacher job performance defined as duties performed by a teacher at a particular period in the school system in achieving organizational goals (Obilade, 1999). Teachers' job performance could be measured through teacher's job satisfaction and job attitudes such as job commitment, feelings of job challenge, job meaningfulness and job responsibility (Cheng, 2002). When an individual is satisfied, their job performance might increase. They tend to be more committed to their work. Job performance is important to ensure the quality of instruction taking place at school. McGregor (1960) developed the theory of job performance in his ' $\mathrm{X}$ ' and ' $\mathrm{Y}$ ' theories. Theory ' $\mathrm{X}$ ' postulates that a negative attribute brings low performance while theory ' $\mathrm{Y}$ ' predicts that positive attributes result in high performance. The theory that a teacher exhibits influences his or her level of performance (Adeyemi, 2004). There are a few reasons contributing to low level of teachers' job performance such as inadequate pay, poor career structure, lack of promotion opportunities, poor school facilities, inadequate school disciplinary policy, principal's leadership behavior and 
students' poor work attitudes and teachers' behavior (George, Louw and Badenhost, 2008). However, this study focus on organizational climate as one of the factors that influence teachers' job performance.

Generally, there is various definition of organizational climate. According to Thompson (2005), organizational climate can be defined as an approach in which organizational members observe and characterize their surrounding and environment in an attitudinal and valuebased manner. In another perspective, Attkinson and Frechette (2009) referred organizational climate as a 'set of attributes specific to a particular organization that may be induced from the organization, deals with its members and its environment'. Even though little is known about organizational climate in the past, however, in the 21st century, organizational climate has received a considerable attention by many sectors. This is due to the fact that organizational climate is often related to school effectiveness (Lazaridou and Tsolakidis, 2011). In educational setting, organizational climate is also referred to as the mixture of interpersonal interaction among the stakeholders of the institutions which include teachers, parents, students and others. As mentioned by Hoy, Tarter and Kottkamp (1991), there are two dimensions of interpersonal interactions which are closely related to organizational climate which are principals' leadership behavior and teachers' behavior. The four dimensions of principals' leadership behavior are aloofness, production emphasis, thrust and consideration while the four dimension of teachers' behavior are disengagement, hindrance, esprit and intimacy. All of these dimensions are served as organizational climate measurement for this study.

According to Halpin (1967), aloofness is defined as principals' behaviour in keeping a social distance from the teachers, by practicing excessive rules and regulations. It indicates that there are some principals who do not possess people-oriented behaviour and tend to be seen as unfriendly. For this type of principals, they normally focus more on the task rather than connecting their emotions and feelings when interacting with the school community members. In his study, Raza (2010) mentioned that the main reason why some principals choose to keep themselves at distance from teachers and avoid intimating with them is because they are very strict about the rules and regulations of the school. In return, they also expect the teachers to obey them spiritually. Nevertheless, a majority of teachers generally do not prefer a principal with autocratic leadership behaviour because it is difficult for them to communicate about any school issues and concerns with them (Raza, 2010). Therefore, aloofness is considered as one of the important factors contributing to the organizational climate. Another aspect of principal's leadership behaviour is the production emphasis. Halpin (1967) stated that the principals' autocratic and controlling behaviour may influence the climate of an organization. The common outcome of this behaviour usually resulted in negative thought among the school community members. In contrast, from the principals' view, they think that the staff will be able to increase their performance and demonstrate a good work when pressure and tension is imposed on them (Raza, 2010). This type of behaviour will affect the organizational climate of the school (Paisey, 1992). However, Paisey (1992) agreed with the notion and argued that if there is no action taken on production, there is a possibility that the staff may not be concerned about their work and the important of accomplishing the organization's vision and mission.

The way principal's act as an icon for 
some types of behaviour expected to be demonstrated by the school community is known as thrust. This kind of principals' behaviour normally encourage the subordinates to achieve and maintain the school standard by setting rules and guidelines pertaining to school standards (Raza, 2010). When the principals are hardworking, it will eventually lead the subordinates to imitate them and enjoy their work. Raza (2010) further stated that principals who acquire a high thrust tend to influence the subordinate positively. This is due to the fact that they are able to inspire the school community to work in accordance to the organization's vision and mission. As a result, when teachers, as one of the school communities, enjoy their work, they tend to improve in their teaching and learning pedagogy and the students will also improve their achievement. On the contrary, principals with no thrust also bring consequences to the climate of the organization (Raza, 2010). This type of principals may not be able to motivate the subordinate and hence, resulted in poor performance (Halpin, 1967). It indicates that thrust is an important element in creating a positive climate of an organization.

In the school organization, it is common for the principals and teachers to discuss and interact with each other concerning schools matters and issues. According to Razi (2010), the interaction between the principals and teachers influence the atmosphere of the school organization. As stated by Halpin (1967), when the principals shows their consideration and concerns to the needs of the subordinates and willing to take personal efforts to solve the problems, teachers, students and parents will also show keen interest with them. Adding to that, when the needs of the subordinates are met, they will be able to do their work smoothly and improve their job performance (Rooney, 2003). This type of behaviour normally has a caring and positive contribution to the school climate (Razi, 2010). This is further strengthening by Azzara (2010) who stated that consideration is the heart of leadership. Principals who are highly considerate is the most effective since building and maintaining a mutually positive relationship with subordinate is a part of leadership behaviour (Azzara, 2010).

Another aspect of organizational climate is teacher's behavior (Raza, 2010). Teacher's behaviour could determine a positive school climate because the way teachers perceive their work, relationship with principals and other teachers determine the school climate. Halpin (1967) has underlined four dimensions of teacher's behaviour are disengagement, hindrance, esprit, and intimacy.

Halpin (1967) defined disengagement as lack of commitment to the institution. Hoy and Sabo (1998) classified teachers who potray's disengagement behavior as individuals who are just "putting in their time". Teacher's who fall under this category enjoy less their work and dislike initiatives or idea from principals and other teachers for the betterment of the school. On the other hand, teachers who have low disengagement, work as a team and committed to their work regardless of their principal's leadership behavior. A study conducted by Gunbayi (2007) reported that young teachers seem to appreciate the value of their job and seem to be more positive and committed in their work compare to the older ones. However, young teachers seem to get impatient quickly when they have to face challenges.

Halpin (1967) described hindrance is a term used to describe some teachers' attitude toward paper work and noninstructional college activities. Owens (1981) further elaborated that teachers who fall under this category are concerned with teaching and perceived rules, paper work and other administrative work quite unnecessary. 
Such teachers only enjoy entering class, teaching, marking books and exam papers. Other work matters like recording marks, keeping class attendance record are not enjoyable. On the contrary, other teacher considers administrative duties not only necessary but also useful in facilitating the achievement of educational goals (Silver, 1983). This is further exemplified by Silver (1983) who highlighted that teacher who take granted of students' attendance, will give way for students to play truant and late coming to school as a common scenario. Raza (2010) added that in cases where teacher are burdened with paper work and administrative duties, teaching and learning process may be affected.

Halpin (1967) described "teachers' satisfaction with their social and professional needs such as help, support, work with each other. A successful school which portrays positive school climate promotes a culture of collaboration, support and trust (Gurr et al, 2005). This is corroborated with the study of Mulford and Edmunds (2009) who stated that collaborative structure for working together is built over a certain duration of time, not something that comes naturally. Teachers' professional needs must also be given consideration. This include attending workshops, seminars, sharing of teaching aids as well as information on pedagogical and content knowledge is important to improve teacher's professional needs.

Intimacy refers to teachers' enjoyment of friendly social relationship with one another (Raza, 2010). Hoy and Miskel (2001) observed that teacher's who have high intimacy know each other well and share personal issues with each other. In addition, they provide strong support for each other and are there for each other during difficult situations. In other words, their closest friends are among their colleagues. When support and encouragement takes place, teachers are able to work with full enthusiasm. As a result of positive relationship, it is likely to contribute to positive climate.

Adeyemi (2008) conducted a study on 360 schools in Ondo State, Nigeria. The findings revealed that most of the schools run an open climate type of organization. However, the level of organizational climate in most of the schools was very low. Besides, the findings of Adeyemi's (2008) also found out that the level of the teachers' job performance was equally low. In terms of the relationship between organizational climate and teachers' job performance, the findings revealed that there was a significant relationship between organizational climate and teachers' job performance.

In terms of organizational climate dimensions, a study conducted by Singh (1985) revealed that the dimensions of organizational climate: aloofness, production emphasis, thrust, consideration, disengagement, esprit, intimacy, and hindrance were found significant correlated with organizational climate of high, average and low performance school. However, John and Taylor (1999) finding was contradicted with Singh (1985) because their study found that only consideration was related with organizational climate. Thus, John and Taylor (1999) agreed that consideration is important in creating a healthy and positive organizational school climate. This is also supported by Rooney (2003) who stated that the principal's ability to meet the needs and wants of teachers will lead to high job performance. In Raza and Arid's (2010) study, they examine the impact of organizational climate on performance of college teachers in Punjabi. The results of their study revealed principals perceived that esprit behavior of teachers and production emphasis behavior of principals were correlated to teachers' job performance. However, most of the principals perceived that their leadership 
behavior such as consideration and aloofness were negatively correlated to teachers' job performance while intimacy behavior of teachers is slightly correlated to teachers' job performance and disengagement behavior of teachers negatively correlated to teachers' job performance. Raza and Arid (2010) also revealed that the majority of the college teachers viewed consideration behavior of principals and intimacy behavior of teachers fairly correlate to their job performance while most of them perceived that thrust behavior of principals and esprit behavior of teachers is highly correlated to their job performance. Besides, the majority of teachers expressed that production emphasis behavior of principals and hindrance behavior of teachers moderately correlated with teachers' job performance. Additionally, the majority of teachers perceived disengagement behavior of teachers slightly correlated with teachers' job performance while aloofness behavior of principals negatively correlated with teachers' job performance.

\section{Research questions}

1.What are the levels of job performance among secondary school teachers in Klang district? 2.What is perceived organizational climate among secondary school teachers in Klang district? 3.What is the relationship of organizational climate and teachers' performance among secondary school teachers in Klang district?

\section{Methodology}

The present study aims to examine the relationship of organizational climate and teachers' job performance. Therefore, based on the research objectives, a descriptive-correlational study is chosen because it describes teachers' perceptions on the variables: organizational climate, job performance and the relationship between these two variables. In selecting a method to conduct descriptive study, a survey method is chosen to collect data from respondents. In this study, a survey method was used to obtain teachers' perception on organizational climate and job performance. In this study, a simple random sampling was employed to determine the secondary school teachers that will be involved in the study. From the selection technique, 37 respondents were selected to fulfil the objectives of this study.

Instrumentation adopted in the study included a questionnaire survey as it has good acceptability, quick response, core consistency, and easy to conduct (Bourdon et al., 2005). The questionnaire was adopted as the main research instrument to assess the level of teachers' job performance and the relationship between organizational climate and teachers' job performance. The questionnaire was adopted and adapted from Raza (2010) and employed seven point Likert scale to indicate respondents response on each item. The questionnaire comprised three sections respectively: Section A (Demographic Profile), Section B (Organizational Climate) and Section C (Teacher's Job Performance). Section A discusses respondents' demographic details such as gender, age, education level, years of teaching experience and current working experience. Section B consists of items that measure the organizational climate and its dimensions. Finally, the items in Section $\mathrm{C}$ were designed to measure teachers' job performance.

Permission to conduct this study was obtained from the studied secondary school. After obtaining the principal's approval, the data and time for the data collection process was arranged. A session has been conducted with all the selected respondents of the study. The researchers described and explained 
clearly the purpose of the study, the importance of completing the questionnaires and also the confidentiality of their responses in which the data would only be utilized for the purpose of this study. The respondents have been given two hours to complete the questionnaires to ensure they have adequate time to indicate their response and return back the completed questionnaire. The returned questionnaires were then coded for example A1, A2, A3 and A4. Then, data cleaning was conducted to examine the questionnaires for duplication and missing values.

For the data analysis, the responses to the questionnaires were analysed using the Statistical Package for Social Sciences (SPSS) version 17 for Windows. With the aid of the SPSS, the data collected from the questionnaire were tabulated and converted into frequency and percentages to describe the demographic profiles and the levels of teachers' job performance. A further analysis is conducted by using descriptive analysis to examine mean and standard deviation scores for perceived organizational climate. Other than that, Pearson's Correlation Moment Coefficient was used to examine the relationship between organizational climate and teachers' performance among secondary school teachers in Klang district.

\section{Findings}

A total of 37 teachers from a daily secondary school teachers participated in this study. Demographic variables of the teachers were extracted by asking questions on gender, age, education level, total number of teaching experience and number of years worked with present school organization. The respondents' demographic information was summarized as displays in Table 1.

\begin{tabular}{|c|c|c|}
\hline Demographic variables & $\begin{array}{c}\text { Frequency } \\
(\mathbf{n}=\mathbf{3 7})\end{array}$ & $\begin{array}{c}\text { Percentage } \\
\%\end{array}$ \\
\hline \multicolumn{3}{|l|}{ Gender } \\
\hline Male & 13 & 35.1 \\
\hline Female & 24 & 64.9 \\
\hline \multicolumn{3}{|l|}{ Age } \\
\hline 23 to 26 years & 6 & 16.2 \\
\hline 27 to 35 years & 17 & 45.9 \\
\hline 36 to 45 years & 13 & 35.1 \\
\hline 46 to 55 years & 1 & 2.7 \\
\hline \multicolumn{3}{|l|}{ Education Level } \\
\hline Diploma & 1 & 2.7 \\
\hline Degree & 34 & 91.9 \\
\hline Masters & 2 & 5.4 \\
\hline $\mathrm{PhD}$ & 0 & 0 \\
\hline \multicolumn{3}{|c|}{ Years of teaching experience } \\
\hline Less than 3 years & 9 & 24.3 \\
\hline 4 to 6 years & 10 & 27.0 \\
\hline 7 to 10 years & 10 & 27.0 \\
\hline More than 10 years & 8 & 21.6 \\
\hline \multicolumn{3}{|c|}{ Years of working with current school } \\
\hline Less than 3 years & 16 & 43.2 \\
\hline 4 to 6 years & 18 & 48.6 \\
\hline 7 to 10 years & 3 & 8.1 \\
\hline More than 10 years & 0 & 0 \\
\hline
\end{tabular}

Table 1. Summary Statistic of Respondents. 
Based on Table 1, the result shows that teaching profession was dominated by female teachers comprised of $64.9 \%$ (24) while only $35.1 \%$ (13) are male teachers. The age distribution reveals that majority of respondents, $45.9 \%$ (17) were 27 to 35 years old. It is also shown that $35.1 \%$ (13) respondents were 36 to 45 years old while $16.2 \%$ (6) respondents fell in the age group of below 26 years old. The remaining $2.7 \%$ (1) respondents fell in the oldest age group of 46 to 55 years old. In terms of education level, the result shows that majority of respondents were degree holder with $91.9 \%$ (34) while only $2.7 \%$ (1) of total respondents were diploma holder. On the other hand, the remaining respondents had obtained post-graduate qualification with $5.4 \% \quad$ (2) of respondents had Master's degree and none had doctorate degree. Regarding their experience as a teacher, $27.0 \%$ (10) respondents have been teaching for 4 to 6 years and 7 to 10 years. On the other hand, $24.3 \%$ (9) respondents were taught for less than 3 years while only $21.6 \%$ (8) respondents had more than 10 years teaching experience. In term of their numbers of service in the present school, majority of respondents, $48.6 \%$ (18) had served more than 4 to 6 years at the present school and $43.2 \%$ (16) respondents indicated they had taught for less than 3 years in the school being studied. Nevertheless, $8.1 \%$ respondents had served 7 years to 10 years at the current school while none had taught for more than 10 years at the school. In sum, of the 37 daily secondary school teachers, the majority are female, that is $64.9 \%$ and $45.9 \%$ had average age of 27 years old to 35 years old. In addition, the majority of the respondents were degree holder with $91.9 \%, 27 \%$ respondents had 4 to 6 years and 7 to 10 years experience in teaching and $48.6 \%$ respondents had taught for 4 to 6 years at the present school.

\begin{tabular}{|c|c|c|}
\hline Level & $\begin{array}{c}\begin{array}{c}\text { Frequency } \\
(\mathbf{n}=37)\end{array} \\
\end{array}$ & $\begin{array}{c}\text { Percentage } \\
\% \\
\end{array}$ \\
\hline Low & 34 & 91.9 \\
\hline Moderate & 3 & 8.1 \\
\hline High & 0 & 0 \\
\hline Total & 37 & 100 \\
\hline
\end{tabular}

Level indicator: 1.00 - 2.99 (Low), 3.00 - 4.99 (Moderate) and 5.00 - 7.00 (High)

Table 2. The Levels of Teachers' Job Performance.

Table 2 displays the levels of job performance among secondary school teachers in Klang district. The findings revealed that majority of them, $91.9 \%$ (34) demonstrated low level of job performance and $8.1 \%$ (3) of total respondents showed moderate level of job performance. Surprisingly, none showed high level of job performance. In the analysis, it was found that the level of teachers' job performance was low. Thus, it could be inferred that secondary school teachers in the Klang district were less likely to carry out the given tasks (Griffin, 2012) such as lesson preparation, teaching and extra curricular activities (Adeyemi, 2008).
Table 3 shows the mean and standard deviation scores for eight dimensions of organizational climate. The mean scores for each dimension are arranged in descending order. The finding suggested that disengagement has the highest mean score among all dimensions (mean $=2.00$, $\mathrm{SD}=0.78$ ). The second highest mean score shows by aloofness (mean $=1.89$, $\mathrm{SD}=0.66)$, followed by production emphasis (mean=1.78, $\mathrm{SD}=0.52)$ and esprit (mean=1.78, $\mathrm{SD}=0.58$ ). The mean and standard deviation scores for other dimensions of organizational climate are consideration $\quad(m e a n=1.70, \quad \mathrm{SD}=0.53)$, thrust (mean=1.70, $\mathrm{SD}=0.53$ ), intimacy 
(mean=1.67, $\mathrm{SD}=0.60$ ) and hindrance (mean=1.54, SD=0.46). As a whole, it could be said that the respondents perceived the level of each organizational climate dimension is low. The findings also showed that the levels of all organizational climate dimensions were low. As discussed in literature review, organizational climate consists of two aspects: principal's leadership behavior and teacher's behavior. The dimensions of principal's leadership behavior are aloofness, production emphasis, thrust and consideration and the dimensions of teacher's behavior are disengagement, hindrance, esprit and intimacy. Therefore, in terms of principal's leadership behavior aspects, it could be inferred that the principal was not an autocratic leader as teachers perceived that the principal was more likely intimating with them, might not strict in implementing the rules and regulations and perhaps, did not expect teachers to obey them (Raza, 2010). The findings of this study also suggested that the principal was less likely to pressurize teachers in attaining school goals and missions, did not modeling professional and positive job behavior to teachers such as punctuality (Raza, 2010) and did not emphasize on teachers' needs and feeling (Hoy and Sabo, 1998). As for teachers' behavior, the dimensions of organizational climate that measure teachers' behavior consist of disengagement, hindrance, esprit and intimacy. The findings of this study showed that the levels for all teachers' behavior dimensions are low. Thus, this inferred that teachers might work as a team and are committed to their work. According to Raza (2010), they were more likely respect each other and conduct themselves as professionals. The principal's negative behavior might not prevent the teachers from being productive in their work. However, teachers were less likely to view non-teaching task as their core task as a teacher. These teachers only concerned with teaching activities. Besides, as suggested by Hoy and Sabo (1998), these teachers might do their work reluctantly. Perhaps, they do not derive satisfaction from their work and they work just to earn a living without any devotion. The findings of this study also implied that teachers might not really know each other well and share personal issues with each other (Hoy and Miskel, 2001).

\begin{tabular}{|c|c|c|c|}
\hline Dimension & Mean & Standard Deviation & Indicator \\
\hline Disengagement & 2.00 & 0.78 & Low \\
\hline Aloofness & 1.89 & 0.66 & Low \\
\hline Production Emphasis & 1.78 & 0.52 & Low \\
\hline Esprit & 1.78 & 0.58 & Low \\
\hline Consideration & 1.70 & 0.53 & Low \\
\hline Thrust & 1.70 & 0.53 & Low \\
\hline Intimacy & 1.67 & 0.60 & Low \\
\hline Hindrance & 1.54 & 0.46 & Low \\
\hline
\end{tabular}

Mean score indicator: 1.00 - 2.99 (Low), 3.00 - 4.99 (Moderate) and 5.00 - 7.00 (High)

Table 3. The Dimensions of Organizational Climate.

\begin{tabular}{|c|c|c|}
\hline Variables & Organizational Climate & $\begin{array}{l}\text { Teachers' Job } \\
\text { Performance }\end{array}$ \\
\hline Organizational Climate & 1 & \\
\hline Teachers' Job Performance & $0.367 * *$ & 1 \\
\hline
\end{tabular}


Table 4 shows the relationship of organizational climate and teachers' job performance. Based on the findings, organizational climate and teachers' job performance demonstrated moderate and positive linear relationship. According to Davis (1971), the $r$ value of +0.30 to +0.49 was considered positive and moderate linear relationship. Further analysis was conducted to examine the relationships of perceived organizational climate dimensions and teachers' job performance as shown in Table 5.

\begin{tabular}{llllllllll}
\hline & TH & HI & AL & PE & CO & DE & ES & IN & PR \\
\hline TH & 1 & & & & & & & & \\
HI & $0.351^{*}$ & 1 & & & & & & & \\
AL & $0.412^{*}$ & 0.256 & 1 & & & & & & \\
PE & $0.558^{* *}$ & 0.187 & $0.625^{* *}$ & 1 & & & & & \\
CO & $0.642^{* *}$ & 0.299 & 0.173 & 0.204 & 1 & & & & \\
DE & 0.017 & $0.378^{*}$ & -0.072 & -0.122 & 0.038 & 1 & & & \\
ES & 0.256 & $0.680^{* *}$ & 0.100 & 0.062 & $0.401^{*}$ & 0.185 & 1 & & \\
IN & 0.255 & 0.257 & 0.274 & 0.187 & $0.574^{* *}$ & 0.065 & $0.353^{*}$ & 1 & \\
PR & $0.356^{*}$ & $0.349^{*}$ & 0.103 & 0.092 & 0.220 & 0.130 & 0.277 & 0.309 & 1 \\
\hline \multicolumn{7}{c}{ Correlation is significant at the 0.05 level (2-tailed) } \\
\multicolumn{7}{c}{ Cronbach Alpha, p $<0.005$}
\end{tabular}

$\mathrm{TH}=$ Thrust, $\mathrm{HI}=$ Hindrance, $\mathrm{PE}=$ Production Emphasis, $\mathrm{CO}=$ Consideration, $\mathrm{DE}=$ Disengagement, $\mathbf{E S}=$ Esprit, $\mathbf{I N}=$ Intimacy and $\mathbf{P R}=$ Teachers' Job Performance

Table 5. Correlation Matrix Analysis of Perceived Organizational Climate Dimensions and Teachers' Job Performance.

The correlation matrix analysis in Table 5 showed that only two dimensions of organizational climate have moderate and positive relationships with teachers' job performance: thrust $(\mathrm{r}=0.356, \mathrm{p}=0.031)$ and hindrance $(\mathrm{r}=0.349, \mathrm{p}=0.034)$ while there are no existed relationship between other organizational climate dimensions such as production emphasis, consideration, disengagement, esprit and intimacy with teachers' job performance. In terms of the relationship between organizational climate and teachers' job performance, the findings revealed that there was a significant relationship between organizational climate and teachers' job performance. The significant relationship found in this study was consistent with Adeyemi (2008). This inferred that healthy organizational climate could enhance teachers' job performance. Further analysis on the dimensions of organizational climate showed that only thrust and hindrance could influence teachers' job performance. The findings were supported by Raza and Arid (2010). As thrust is one aspect of principal leadership behavior, it implied that principal that modeling professional work behavior such as involve in all school activities, hard working, committed in work and interested in new educational developments might able to enhance teachers' job performance. Whereas principal leadership behavior that lack of thrust might create under performing teachers (Raza and Arid, 2010). Another dimension of organizational climate that could enhance teachers' job performance was from teacher behavior: hindrance. Based on the finding, it could be inferred that teachers' negative perception on nonteaching tasks could affect their job performance. According to Raza and Arid (2010), teachers who were overloaded with clerical tasks which unrelated to teaching might not able to show high level of job performance. These teachers were more likely concerned with teaching tasks but feel that paper work and clerical tasks such as preparing lesson note, keeping class attendance record and recording test marks were less likely necessary, thus affect their job performance. 


\section{Implications and recommendations}

The findings revealed that most of teachers in a secondary school in the district of Klang were under performed in their tasks and organizational climate dimensions such as thrust and hindrance were found as crucial factors in enhancing teachers' job performance. This implied that principal as a school leader should maintain or create a healthy climate in school organization to enhance better job performance among teachers by dwelling more on human behavior. Principal needs to demonstrate more leadership behavior than managerial behavior. For example, principal could shows concern for teachers, motivates them to exert their best in the tasks given and does not allow clerical tasks to disrupt teachers' instructional responsibilities. Thus, based on the findings of this study, the followings are some recommendations that would be beneficial for the future practices and future researches. It was found that perceived principal leadership behavior such as thrust could affect teachers' job performance. Thus, it is recommends that continuous in service training should be conducted to improve principal leadership behavior. The training perhaps could emphasize on principal leadership behavior that create healthy organizational climate. As the findings showed that organizational climate was a crucial factor in enhancing teachers' job performance, principal perhaps could create a committee that accountable in assessing organizational climate among teachers. According to Ginbayi (2007), organizational climate assessment might help in finding the obstacles to teachers' job performance.

\section{References}

Adeyemi, T.O. (2008). Organisational Climate and Teachers' Job Performance in Primary Schools in Ondo State, Nigeria: An Analytical Survey. Asian Journal of Information Technology, 7(4), 138-145. [Full text] [Back to text]

Attkinson, T. \& Frechette, H. (2009). Creating a positive organizational climate in a negative economic one. Improving Organizational Climate to Transform Performance. FORUM transforming performance. [Full text] [Back to text]

Bourdon, K.H., Goodman, R., Simpson, G. \& Koretz, D.S. (2005). The strengths and difficulties questionnaire: U.S. normative data and psychometric properties. Journal of the American Academy of Child \& Adolescent Psychiatry, 44(6), 557-564. [Abstract] [Back to text]

Griffin, R.W. (2012). Management. Mason, USA: South- Western College Pub. [Full text] [Back to text]

Gunbayi, I. (2007). School climate and teachers' perceptions on climate factors: Research into nine urban high schools. The Turkish Online Journal of Educational Technology, 6(3), 70-78. [Full text] [Back to text]

Halpin, A.W. (1967). Change and organizational climate. Journal of Educational Administration, 5(1), 5-25. [Full text] [Back to text]

Hoy, W.K., Tarter, C.J. \& Kottkamp, 
R.B.

(1991).

Open

Schools/Healthy Schools:

Measuring Organizational

Climate. London: Sage

Publication. [Back to text]

Hoy, W. K. \& Sabo, D. J. (1998). Quality Middle School: Open and Healthy. California: Corwin Press Inc. [Abstract] [Back to text]

Hoy, W.K. and Miskel, C.G. (2001). Educational Administration: Theory, Research and Practice. 6th edition. New York: McGraw-Hill. [Back to text]

John, M.C. \& Taylor, J.W. (1999). Leadership Style, School Climate, and the Institutional Commitment of Teachers. International Forum, 2(1), 2557. [Back to text]

Lazaridou, A. \& Tsolakidis, I.G. (2011). An exploration of organizational climate in Greek high school. [Back to text]

Paisey, A. (1992). Organisation and Management in Schools. 2nd edition. New York: Longman publishing. [Abstract] [Back to text]

Raza, S.A. (2010). Relationship between organizational climate and performance of teachers in public and private colleges of
Punjab. (Doctoral dissertation, University Institute of Education and Research, Pir Mehr Ali Shah, Arid Agriculture University Rawalpindi and University Rawalpindi). [Full text] [Back to text]

Raza, S.A. \& Shah Arid, P.M.A. (2010). Impact Of Organizational Climate On Performance Of College Teachers In Punjab. Journal of College Teaching \& Learning, 7(10), 47-52. [Full text] [Back to text]

Rooney, J. (2003). Principals Who Care: A Personal Reflection. Educational Leadership, 60(6), 76-79. [Abstract] [Back to text]

Singh, S. (1985). A study of school climate, leadership behavior and moral development of the heads of elementary and secondary schools. (Doctoral dissertation Unpublished). Punjab University, India. [Back to text]

Thompson,

M.D.

(2005).

Organizational climate perception and job element satisfaction: A multi-frame application in a higher education setting. E-Journal of Organizational Learning and Leadership, 4(1). [Full text] [Back to text] 